\section{Molecular Syndromology}

Mol Syndromol 2018;9:22-24

DOI: $10.1159 / 000479359$
Accepted: May 26, 2017

by M. Schmid

Published online: August 12, 2017

\title{
A Novel Missense Variant in the PVRL4 Gene Underlying Ectodermal Dysplasia-Syndactyly Syndrome in a Turkish Child
}

\author{
Leila Dardour $^{\mathrm{a}}$ Katrien Cosyns $^{\mathrm{b}}$ Koenraad Devriendt $^{\mathrm{a}}$ \\ ${ }^{a}$ Center for Human Genetics, University of Leuven (KU) and University Hospital Leuven (UZ), Leuven, and \\ ${ }^{\mathrm{b}}$ Department of Pediatrics, Regionaal Ziekenhuis, Tienen, Belgium
}

\section{Keywords}

Ectodermal dysplasia $\cdot$ PVRL4 Syndactyly

\begin{abstract}
Ectodermal dysplasia-syndactyly syndrome is a rare autosomal recessive congenital disorder caused by mutations in PVRL4 coding for nectin-4. Five different mutations in the PVRL4 gene, including 3 homozygous missense mutations, have been reported. Here, we present an unreported missense variant (c.247C $>\mathrm{T}$, p.His83Tyr) in a consanguineous Turkish family.

๑) 2017 S. Karger AG, Basel
\end{abstract}

Ectodermal dysplasia-syndactyly syndrome (EDSS1; OMIM 613573) is a rare form of ectodermal dysplasia. It is a clinically and genetically heterogeneous group of disorders characterized by alterations in 2 or more ectodermal appendages. [Freire-Maia, 1971; Brancati et al., 2010; Raza et al., 2015].

EDSS1 typically affects hair, nails, teeth, and sweat glands with cutaneous syndactyly of the fingers and/or toes. Abnormalities in the hair morphology include pili torti and swelling along the shafts with a tendency to

\section{KARGER}

๑๑ 2017 S. Karger AG, Basel

E-Mail karger@karger.com

www.karger.com/msy break [Brancati et al., 2010]. Eyebrows, eyelashes, and body hair are also sparse. The nails are hypoplastic. Dental findings consist of abnormally widely spaced teeth, with peg-shaped and conical crowns. Patients may have hypo- or hyperhidrosis.

The disease is very rare, and so far only 5 families are reported worldwide. Since the identification of the first causative mutation in the poliovirus receptor-related 4 gene (PVRL4; OMIM 609607) by Brancati et al. [2010], only 5 mutations have been reported to date [Brancati et al., 2010; Jelani et al., 2011; Fortugno et al., 2014; Raza et al., 2015].

Here, we report clinical and genetic data in a sixth family with this very rare disorder.

\section{Case Report}

The patient is the first child of healthy parents of Turkish descent. The parents are related, first cousins once removed. Family history is negative with regard to congenital malformations or similar disorders as seen in the child.

The girl was referred for etiologic diagnosis at the age of 2.5 years. Her psychomotor development and growth were normal. Biometrics were normal; the girl's weight was $11.9 \mathrm{~kg}(-0.9 \mathrm{SD})$, height 88.3 $\mathrm{cm}(-0.8 \mathrm{SD})$, and head circumference was $48 \mathrm{~cm}(-0.4 \mathrm{SD})$. She had dry, sparse scalp hair and eyebrows, with slightly increased hair

Prof. Dr. Koenraad Devriendt

Center for Human Genetics, KU Leuven and UZ Leuven Herestraat 49, Box 602

BE-3000 Leuven (Belgium)

E-Mail koenraad.devriendt@ uzleuven.be 
Table 1. Cases previously reported and present case

\begin{tabular}{|c|c|c|c|c|c|}
\hline Reference & $P V R L 4$ variant & Mutation type & Protein & Family/origin & Clinical features \\
\hline \multirow{3}{*}{$\begin{array}{l}\text { Brancati } \\
\text { et al. } \\
2010\end{array}$} & c. $851 \mathrm{G}>\mathrm{A}($ exon 4$)$ & $\begin{array}{l}\text { homozygous } \\
\text { missense mutation }\end{array}$ & p.Arg284Gln & $\begin{array}{l}\text { Algerian, } 4 \text { siblings, } \\
\text { consanguineous parents }\end{array}$ & \multirow{3}{*}{$\begin{array}{l}\text { partial cutaneous syndactyly, variably } \\
\text { involving fingers and toes; sparse and coarse } \\
\text { hair, with a tendency to break; identical } \\
\text { abnormalities of eyebrows, eyelashes, and } \\
\text { body hair; progressive hair loss that resulted } \\
\text { in complete alopecia; abnormally widely } \\
\text { spaced teeth, with peg-shaped and conical } \\
\text { crowns; normal sweating }\end{array}$} \\
\hline & c. $554 \mathrm{C}>\mathrm{T}($ exon 3$)$ & $\begin{array}{l}\text { compound } \\
\text { heterozygous: } \\
\text { missense }\end{array}$ & p.Thr185Met & \multirow[t]{2}{*}{$\begin{array}{l}\text { Italian, } 2 \text { siblings, } \\
\text { nonconsanguineous parents }\end{array}$} & \\
\hline & c.906delT (exon 5) & frameshift & p.Pro304HisfsX2 & & \\
\hline $\begin{array}{l}\text { Jelani } \\
\text { et al. } \\
2011\end{array}$ & c.635C4G (exon 3) & $\begin{array}{l}\text { homozygous } \\
\text { missense mutation }\end{array}$ & p.Pro212Arg & $\begin{array}{l}\text { Pakistani, consanguineous } \\
\text { family, with } 10 \text { affected } \\
\text { individuals }\end{array}$ & $\begin{array}{l}\text { sparse scalp hair, sparse to absent eyebrows } \\
\text { and eyelashes; conical- and cylindrical- } \\
\text { shaped teeth with ill-defined surface } \\
\text { morphology and enamel hypoplasia; } \\
\text { hypoplastic finger and toe nails with nail } \\
\text { plate degeneration and hyperkeratosis over } \\
\text { the palms; bilateral cutaneous syndactyly of } \\
\text { fingers and toes; no hypo- or hyperhidrosis }\end{array}$ \\
\hline $\begin{array}{l}\text { Fortugno } \\
\text { et al. } \\
2014\end{array}$ & c.724G4A (exon 3) & $\begin{array}{l}\text { homozygous } \\
\text { missense mutation }\end{array}$ & p.Val242Met & $\begin{array}{l}\text { Afghan, consanguineous } \\
\text { parents with } 3 \text { affected } \\
\text { individuals }\end{array}$ & $\begin{array}{l}\text { cutaneous syndactyly, involving fingers } 2-4 \\
\text { and toes } 2-5 \text {; pili torti; progressive hair loss, } \\
\text { leading to complete alopecia in the second } \\
\text { decade of life; abnormally widely spaced and } \\
\text { hypoplastic teeth; heat intolerance in } \\
\text { individuals }\end{array}$ \\
\hline Present case & c. $247 \mathrm{C}>\mathrm{T}($ exon 2$)$ & $\begin{array}{l}\text { homozygous } \\
\text { missense mutation }\end{array}$ & p.His83Tyr & $\begin{array}{l}\text { Turkish, consanguineous } \\
\text { parents }\end{array}$ & $\begin{array}{l}\text { dry, sparse hair; small widely spaced teeth } \\
\text { with conical crowns; small, thin, and brittle } \\
\text { nails; dry skin with irregular regions of } \\
\text { hypopigmentation; normal sweating; } \\
\text { cutaneous syndactyly of toes } 3-5 \text { and mild } \\
\text { webbing between the fingers } 2-3\end{array}$ \\
\hline
\end{tabular}

In all cases, the affected domain is the second immunoglobulin-like domain of nectin- 4 .

growth on the back. She had small widely spaced teeth with conical crowns. The nails were small, thin, and brittle, especially on the toes. She had dry skin with irregular regions of hypopigmentation. In addition, she had a cutaneous syndactyly of toes $3-5$ and mild webbing between the second and third fingers (Fig. 1). She sweated normally. The nipples were slightly hypoplastic.

\section{Method and Results}

\section{Genetic Analysis}

To unravel the genetic defect of EDSS, targeted sequencing of the PVRL4 gene in the patient was performed. All coding exons of the PVRL4 gene (NM_030316 NP_112178) were amplified by PCR and subsequently analyzed by direct sequencing. The resulting sequences were aligned to database reference sequences and scanned for mutations. A single homozygous $\mathrm{C}$ to $\mathrm{T}$ substitution in exon 2 was identified in the patient $(c .247 \mathrm{C}>\mathrm{T})$, resulting in a missense mutation (p.His83Tyr).

This variant was neither found in population databases (ExAC, 1000 Genome, and Exome Variant Server) nor in disease databases (OMIM, ClinVar). The variant is predicted to be pathogenic by in silico predictive algorithm (MutationTaster).

Novel Missense Variant in PVRL4 and EDSS1
The mutated His 83 residue is located in the second immunoglobulin-like V-type 1 domain of nectin- 4 and is highly conserved among species ( 5 species among 6 ).

\section{Discussion}

EDSS1 is a very rare autosomal recessive disorder, with only 5 families reported to date.

EDSS1 is caused by recessive mutations in the PVRL4 gene. This gene contains 9 exons and encodes a 510-amino acid nectin-4 protein, an emerging class of molecules acting in cooperation with cadherins to form cell-cell adhesion, especially at adherens junctions. Brancati et al. [2013] proposed the term "nectinopathies" for disorders caused by mutations in nectins. Besides EDSS1 (nectin-4 ectodermal dysplasia), this would also encompass nectin-1 ectodermal dysplasia (cleft lip/palate ectodermal dysplasia; CLPED1; OMIM 225060) [Brancati et al., 2013].

Mol Syndromol 2018;9:22-24

DOI: $10.1159 / 000479359$ 


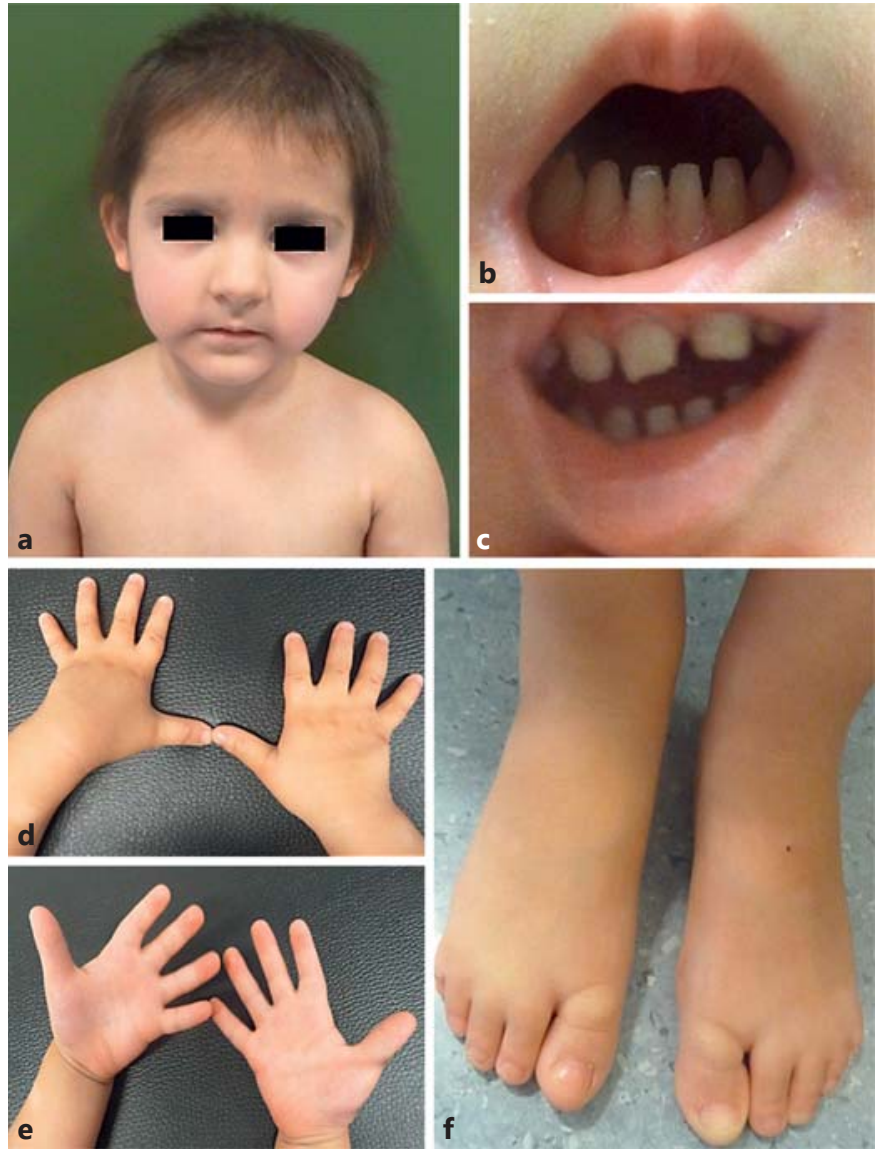

Fig. 1. Clinical features of ectodermal dysplasia-syndactyly syndrome. a Dry and sparse hair and eyebrows. b, c Small widely spaced teeth with conical crowns. d, e Bilateral webbing between the 2 nd and 3 rd fingers. $f$ Bilateral cutaneous syndactyly of toes 3-5.
In the literature, 3 homozygous missense, 1 homozygous nonsense, and 1 compound heterozygous (missense and frameshift) mutations of this gene have been described in 5 families. Clinical and genetic data are summarized in Table 1 [Brancati et al., 2010; Jelani et al., 2011; Fortugno et al., 2014; Raza et al., 2015].

The missense mutation described here (p.His83Tyr) is novel and affects a highly conserved amino acid in the Vtype1 immunoglobulin-like segment of the PVRL4 protein, the same domain where the other missense mutations have been described before. Our patient shows the characteristic phenotype described in the other families. However, as outlined in Table 1, there is variability in phenotypic expression. For instance, sweating is highly variable with a different intolerance to heat. In our case, the main distinctive feature is lack of hair loss; however, the girl is still very young, and in some cases, hair loss was described in the third decade of life.

In conclusion, we confirm a novel PVRL4 mutation in the present family leading to the characteristic features of EDSS1.

\section{Statement of Ethics}

Genetic analysis for the patient was performed after obtaining parental informed consent, in a clinical diagnostic setting. Permission was granted for the publication of this paper and the accompanying patient's photographs. This study was approved by the KU Leuven University Hospitals Ethical Committee (B322201010111-S52853).

\section{Disclosure Statement}

The authors have no conflicts of interest to declare.

\section{References}

Brancati F, Fortugno P, Bottillo I, Lopez M, Josselin E, et al: Mutations in PVRL4, encoding cell adhesion molecule nectin-4, cause ectodermal dysplasia-syndactyly syndrome. Am J Hum Genet 87:265-273 (2010).

Brancati F, Agolini E, Fortugno P: Nectinopathies: an emerging group of ectodermal dysplasia syndromes. G Ital Dermatol Venereol 148:59-64 (2013).

Fortugno P, Josselin E, Tsiakas K, Agolini E, Cestra G, et al: Nectin-4 mutations causing ectodermal dysplasia with syndactyly perturb the Racl pathway and the kinetics of adherens junction formation. J Invest Dermatol 134: 2146-2153 (2014)
Freire-Maia N: Ectodermal dysplasias. Hum Hered 21:309-312 (1971).

Jelani M, Chishti MS, Ahmad W: Mutation in PVRL4 gene encoding nectin-4 underlies ectodermal-dysplasia-syndactyly syndrome (EDSS1). J Hum Genet 56:352-357 (2011).

Raza SI, Nasser Dar R, Shah AA, Ahmad W: A novel homozygous nonsense mutation in the PVRL4 gene and expansion of clinical spectrum of EDSS1. Ann Hum Genet 79:92-98 (2015). 